\title{
Clinoptilolite of Possible Economic Value in Sedimentary Deposits of the Conterminous United States
}

G E O L O G I C A L S UR V E Y B ULLE TIN 133 2-B

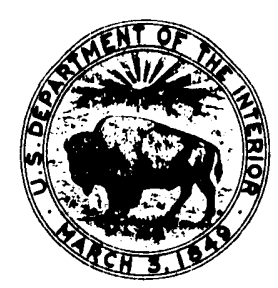

QE 75

B 9

$$
\text { No. } 6
$$




\section{Clinoptilolite of Possible Economic Value in Sedimentary Deposits of the Conterminous United States}

By RICHARD A. SHEPPARD

CONTRIBUTIONSTO ECONOMIC GEOLOGY

GE OL O G C A L S UR VEY B ULLET I N 1332 - B 


\section{UNITED STATES DEPARTMENT OF THE INTERIOR}

ROGERS C. B. MORTON, Secretary

\section{GEOLOGICAL SURVEY}

William T. Pecora, Director

Library of Congress catalog card No. 78-610524

For sale by the Superintendent of Documents, U.S. Government Printing Office Washington, D.C. 20402 - Price 20 cents 


\section{CONTENTS}

Page

Abstract

Introduction

Acknowledgment

Chemical and physical properties.

Occurrences.

Economic considerations.

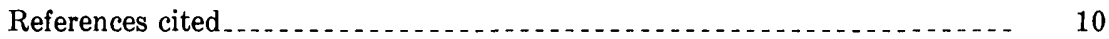

\section{ILLUSTRATIONS}

Page

Figure 1. Plot showing the compositional variation of clinoptilolite and

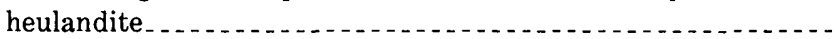

2. X-ray diffractometer trace of clinoptilolite from a tuff bed in the Barstow Formation of California.................................

3. Map showing occurrences of clinoptilolite in sedimentary rocks of the conterminous United States.

\section{TABLE}

TABLE 1. Occurrences of clinoptilolite in sedimentary rocks of the conterminous United States 


\title{
CONTRIBUTIONS TO ECONOMIC GEOLOGY
}

\section{CLINOPTILOLITE OF POSSIBLE ECONOMIC VALUE IN SEDIMENTARY DEPOSITS OF THE CONTERMINOUS UNITED STATES}

\author{
By Richard A. ShePPARD
}

\begin{abstract}
Clinoptilolite is a very common zeolite, and it has formed in sedimentary rocks of diverse lithology, age, and depositional environment. Extensive and nearly monomineralic beds of clinoptilolite are especially common in Cenozoic rocks that originally contained silicic vitric material. Clinoptilolite is potentially valuable for many industrial and agricultural processes, and it may find extensive use in the control of water pollution by the removal of ammonia from wastewater.
\end{abstract}

\section{INTRODUCTION}

This report summarizes the chemical and physical properties of the zeolite clinoptilolite and briefly discusses its occurrence in sedimentary deposits of the conterminous United States. Clinoptilolite is potentially valuable for many industrial processes, and it may find extensive use in the control of water pollution as an agent for the removal of ammonia from wastewater (Mercer, 1969).

Zeolites are among the most common authigenic silicate minerals that occur in sedimentary rocks. They have formed in rocks that are diverse in lithology, age, and depositional environment (Hay, 1966). Authigenic zeolites are especially common in Cenozoic sedimentary rocks that originally contained silicic vitric material. Nearly monomineralic beds of zeolite are known from many areas of the United States, but most zeolitic sedimentary rocks consist of two or more zeolites as well as clay minerals, silica minerals, and feldspars of authigenic origin. Zeolitic rocks also commonly contain relict vitric material and pyrogenic or detrital grains.

Clinoptilolite is probably the most abundant authigenic zeolite that occurs in sedimentary rocks. The original description of clinoptilolite was of material from amygdales in a basaltic rock from Wyoming (Pirsson, 1890; Schaller, 1932). Occurrences of this zeolite, however, have subsequently been reported chiefly from sedimentary rocks, especially those originally rich in silicic vitric material. 


\section{ACKNOWLEDGMENT}

Grateful appreciation is expressed to those colleagues in the U.S. Geological Survey who contributed to this assembly of data on occurrences of clinoptilolite.

\section{CHEMICAL AND PHYSICAL PROPERTIES}

Clinoptilolite is a member of the heulandite structural group. Although there is still some disagreement on the distinction between the closely related zeolites of this group, most workers agree that clinoptilolite is the Si-rich (Hey and Bannister, 1934; Mumpton, 1960) and alkali-rich member (Mason and Sand, 1960). The compositions of clinoptilolite and heulandite from various rock types are presented in figure 1. Except for a slight overlap in the $\mathrm{Si}: \mathrm{Al}+\mathrm{Fe}^{+3}$ and $\mathrm{Na}+\mathrm{K}: \mathrm{Na}+\mathrm{K}+\mathrm{Ca}+\mathrm{Mg}$ ratios, plots of the compositions form two clusters. Heulandite characteristically has a $\mathrm{Na}+\mathrm{K}: \mathrm{Na}+\mathrm{K}+\mathrm{Ca}+\mathrm{Mg}$

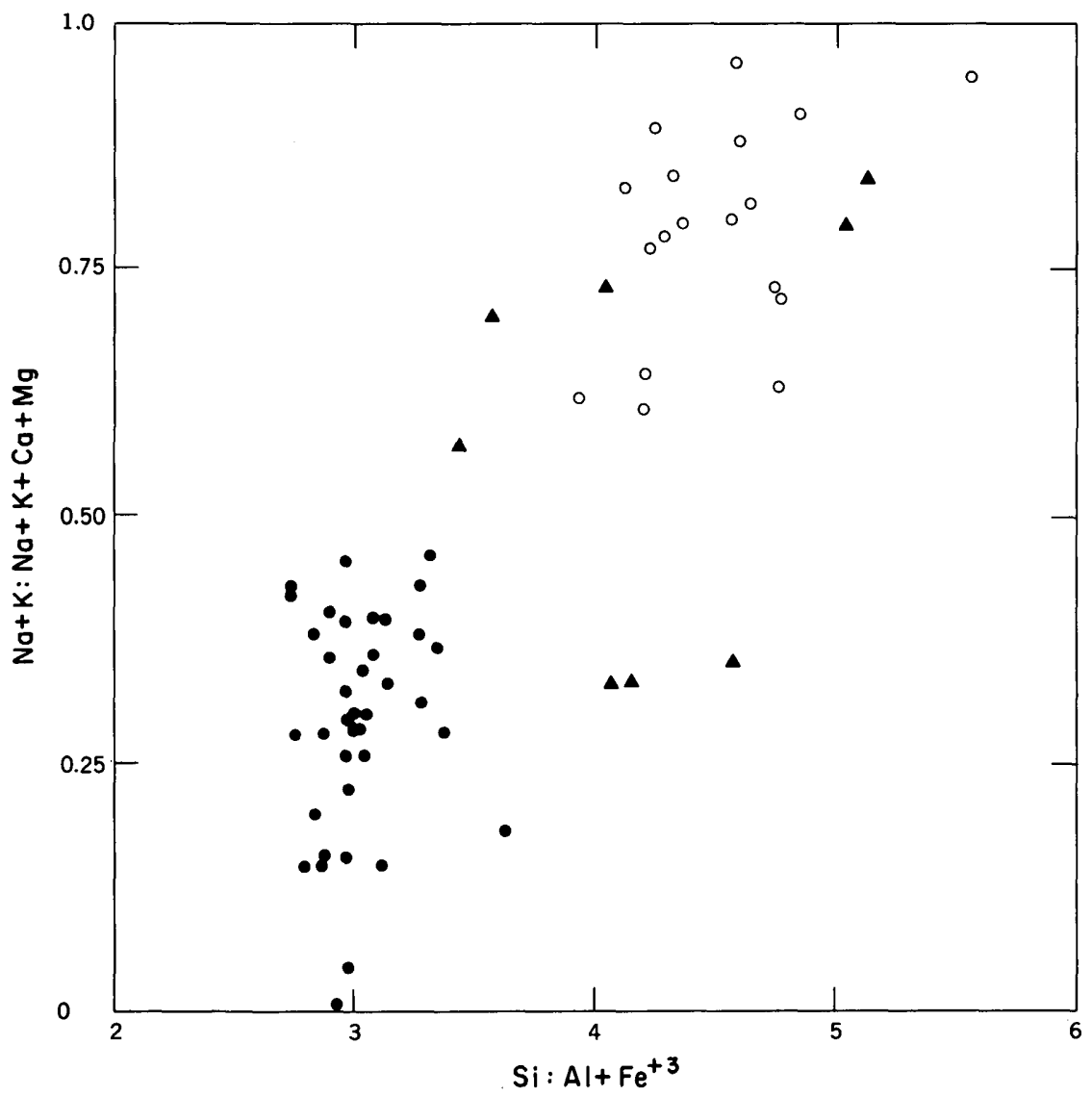

Figure 1.-Plot showing the compositional variation of clinoptilolite and heulandite. $O$, clinoptilolite from sedimentary rocks; $\boldsymbol{\Delta}$, clinoptilolite from volcanic rocks; 0 , heulandite from igneous rocks. 
ratio less than 0.5 and a $\mathrm{Si}: \mathrm{Al}+\mathrm{Fe}^{+3}$ ratio near 3 , whereas most clinoptilolites have a $\mathrm{Na}+\mathrm{K}: \mathrm{Na}+\mathrm{K}+\mathrm{Ca}+\mathrm{Mg}$ ratio greater than 0.6 and range in $\mathrm{Si}: \mathrm{Al}+\mathrm{Fe}^{+3}$ ratio from about 4.0 to 5.0. The clinoptilolites from sedimentary rocks show a range in $\mathrm{Si}: \mathrm{Al}+\mathrm{Fe}^{+3}$ ratio of about 3.9-5.6. Sodium is the predominant cation in most clinoptilolites; however, potassic clinoptilolites are known in California (Sheppard and others, 1965) and in Japan (Minato and Takano, 1964). The few analyzed clinoptilolites that have a $\mathrm{Na}+\mathrm{K}: \mathrm{Na}+\mathrm{K}+\mathrm{Ca}+\mathrm{Mg}$ ratio less than 0.6 are calcic specimens from volcanic rocks in Bulgaria (Kirov, 1965) and in Italy (Alietti, 1968).

Indices of refraction and thermal treatment have also been used to distinguish clinoptilolite from heulandite. Mason and Sand (1960) suggested that clinoptilolite can be identified by a $\beta$ index of refraction of 1.485 or lower and that heulandite can be identified by a $\beta$ index of 1.488 or higher. Most clinoptilolites from sedimentary rocks have a mean index of refraction of 1.471-1.483 and a low birefringence of about 0.003 . Heulandite is thermally unstable above about $250^{\circ} \mathrm{C}$, whereas clinoptilolite is stable to at least $750^{\circ} \mathrm{C}$ (Mumpton, 1960; Shepard and Starkey, 1964). However, some members of the heulandite structural group from sedimentary rocks display anomalous optical properties and exhibit anomalous thermal behavior, and these members cannot be conveniently classified as clinoptilolite or heulandite (Hay, 1963; Shepard, 1961).

Clinoptilolite occurs as platy or prismatic crystals that are $0.005-0.3$ $\mathrm{mm}$ (millimeter) long; however, most clinoptilolite crystals are $0.01-$ $0.02 \mathrm{~mm}$ long. Some of the large clinoptilolite crystals show progressive or oscillatory zoning (Sheppard and Gude, 1969b, p. 13). Because of the relatively small crystal size and the optical and physical properties that are similar to the other authigenic zeolites, X-ray powder diffraction techniques are generally used for positive identification of clinoptilolite. A typical X-ray diffractometer trace of clinoptilolite is shown in figure 2.

\section{OCCURRENCES}

Clinoptilolite is the zeolite most often reported from sedimentary deposits in recent years, and it occurs in many rock types from lacustrine, fluviatile, and marine environments (table 1, fig. 3). Although clinoptilolite is most abundant in rocks of Cenozoic age, it has been found in rocks as old as Jurassic in New Mexico (E. S. Santos, oral commun., 1970). Occurrences of clinoptilolite are especially common in the Western United States. Clinoptilolite is also a common and locally abundant constituent in Tertiary sedimentary rocks of the Coastal Plain from southeastern Texas to North Carolina and northward to western Kentucky (fig. 3).

At the localities listed in table 1 the clinoptilolite content of the rock samples ranges from less than 1 percent to nearly 100 percent. 


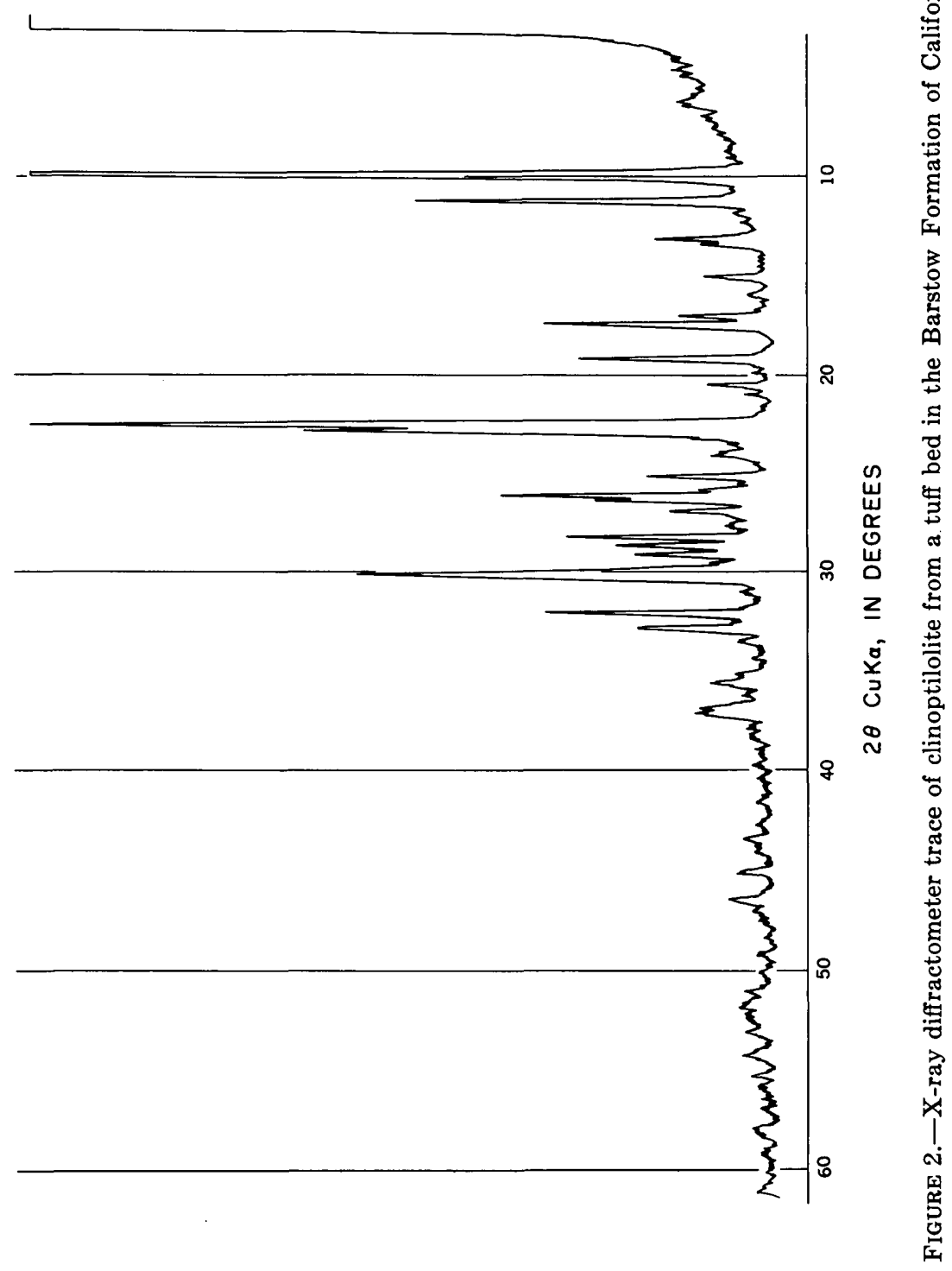




\section{TABLE 1.-Occurrences of clinoptilolite in sedimentary rocks of the conterminous United States}

[Locality numbers are shown in figure 3. Asterisk $\left(^{*}\right)$ indicates localities where beds are at least 1 foot thick and contain at least 75 percent clinoptilolite]

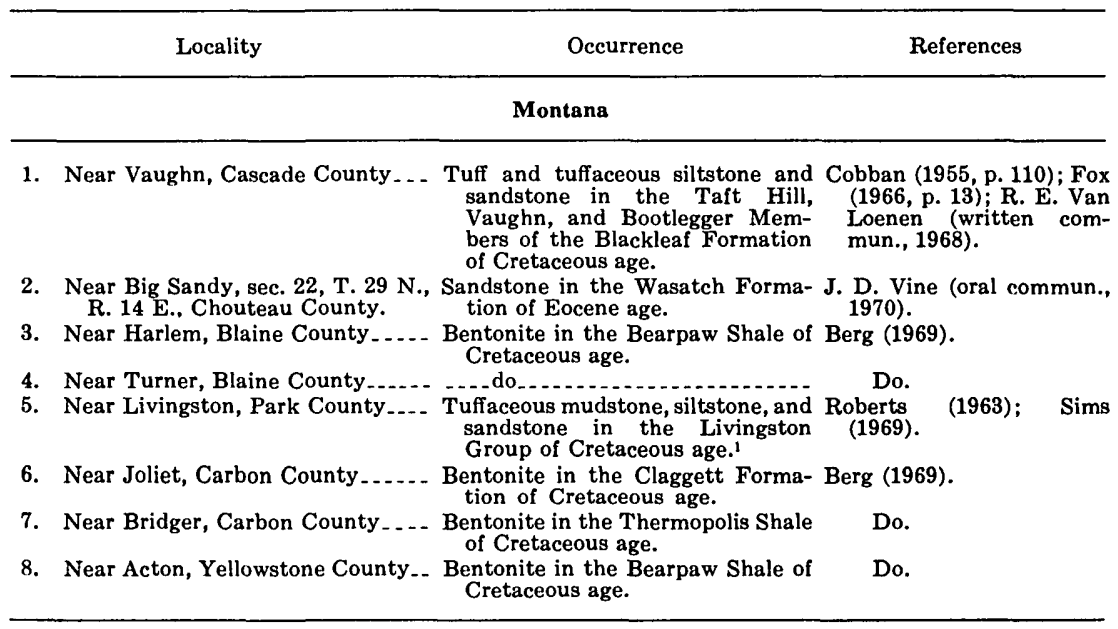

\section{Idaho}

9. Near Preston, Franklin County*. - Tuff in the Salt Lake Group of late Deffeyes (1959a). Tertiary age.

\section{Washington}

10. Near Renton, King County _. . . . Sandstone and conglomerate in un- D. R. Mullineaux (oral named marine formation of commun., 1969). Oligocene age.

\section{Oregon}

11. Near Bearbones Mountain, Lane County.*

12. Near Stein's Pillar, Crook County

13. Near the Painted Hills, Wheeler County.*

14. Near Deep Creek, Wheeler County.*

15. Swayze Creek, near Durkee, Baker County.

16. Sucker Creek, Malheur Count

17. Near Sheaville, Malheur County*

8. Near Rome, Malheur County

19. East face of Steens Mountain, Harney County.

20. Near Harney Lake, Harney County.*

21. West face of Hart Mountain Lake County.*
Tuff and lapilli tufi in the Little Moore and Peck (1962, p. Butte Volcanic Series of Oligo- 188); Peck and others cene and Miocene age.

Tuff in the John Day Formation of Waters (1966). Oligocene and Miocene age.

Tuff and claystone in the lower part Hay $(1962,1963)$. of the John Day Formation of Oligocene and Miocene age.

Tuff in the lower part of the John Fisher $(1962,1963)$; Wilcox Day Formation of Oligocene and and Fisher (1966). Miocene age.

Tuff in unnamed lacustrine forma- A. J. Gude 3d (oral comtion of Pliocene age. mun., 1970).

Tuff and tuffaceous sandstone in the Kittleman and others Sucker Creek Formation of Mio- (1965). cene age.

Tuff probably equivalent to part of Sheppard and Walker the Sucker Creek Formation of (1969). Miocene age.

Tuff and tuffaceous sandstone in Regis and Sand (1966) unnamed lacustrine formation of Studer (1967); Sheppard Pliocene age.

Tuff in the Pike Creek Formation of Walker and Repenning Oligocene(?) and Miocene age. (1965).

Tuff and tuffaceous sedimentary Walker and Swanson rocks in the Danforth Formation (1968a). of Pliocene age.

Tuff and tuffaceous sedimentary Walker and Swanson rocks of late Oligocene or early (1968b). Miocene age.

1 Zeolite identified as heulandite. 
TABLE 1.-Occurrences of clinoptilolite in sedimentary rocks of the conterminous United States-Continued

\begin{tabular}{ccc}
\hline Locality & Occurrence & References \\
\hline
\end{tabular}

Wyoming Member of the Pierre Shale of (1933); J. R. Gill (or Cretaceous age. commun., 1970). 23. Southeast flank of North Butte, Sandstone in the Wasatch Forma- J. D. Vine (oral commun.,
tion of Eocene age.

Tuff in the Tepee Trail Formation J. D. Love (written comSprings County.*
onake River Canyon, Lincoln
Shale in the Aspen Formation of Heinrich (1963).

25. Snake River Canyon, Lincoln County.

26. Near Cameron Spring on Beaver Rim, Fremont County. Cretaceous age. 1

Tuffaceous sandstone in the White Van Houten $(1964$, p. 65). River Formation of Oligocene age.

27. Beaver Rim, Fremont County* ... Tuff in the Wagon Bed Formation Van Houten (1964); Boles of Eocene age.

28. Near Split Rock, Natrona County.*

Tuff in the Moonstone Formation Love (1970). of Pliocene age.

29. Near Green River, Sweetwater County.

Tuff in the Tipton Shale Member of Goodwin and Surdam the Green River Formation of (1967) Eocene age.

30. Near Twin Buttes, Sweetwater Tuff and tuffaceous sandstone in R. A. Sheppard (unpub. County.*

the Bridger Formation of Eocene data).

age.

\section{South Dakota}

31. Near Chamberlain, Buffalo County.

32. Sheep Mountain Table, Shannon County.*
Bentonite in the Sharon Springs Schultz (1963). Member of the Pierre Shale of Cretaceous age.

Tuff in the Arikaree Formation of Schultz (1961). Miocene age.

\section{Colorado}

33. Near Vermillion Cliffs, sec. 30, T. Tuff in the Bridger Formation of A. J. Gude 3d (oral com10 N., R. 98 W., Moffat County.* Eocene age.

34. Near Como, sec. 11, T. 8 S., R. 76 Tuff and tuffaceous sandstone in D. G. Wyant (oral comW., Park County. the Denver Formation of Late mun., 1970). Cretaceous and Paleocene age.

35. Near Creede, Mineral County*.... Tuff in the Windy Gulch Member Ratté and Steven (1967, p. of the Bachelor Mountain Rhyo- H7). lite of Oligocene age.

\section{Utah}

36. Near Mountain Green, sec. 24, T. Tuff in the Salt Lake Formation of R. A. Sheppard (unpub. 5 N., R. 1 E., Morgan County.* Tertiary age. data).

37. Eastern flank of Topaz Mountain, Tuff in unnamed formation of Plio- D. A. Lindsey (oral comsec. 5, T. 13 S., R. 11 W., Juab cene(?) age. County.*

38. Gunnison Plateau, sec. 12, T. 16 S., Sandstone in the Colton Formation J. D. Vine (oral commun., R. 1 E., Juab County.

39. Northern part of the Markagunt Tuffaceous sandstone of Oligocene Anderson (1969). Plateau, Iron County. and Miocene(?) age.

\section{Nevada}

40. Near Elko, Elko County.......... Oil shale in unnamed formation of Deffeyes (1959a). Oligocene age.

41. Near Carlin, Eureka County*..... Tuff in the Safford Canyon Forma- Deffeyes (1959a); Regnier tion of Oligocene(?) or Mio- (1960) cene(?) age and the Carlin Formation of Pliocene age.

42. West flank of the Shoshone Range, Tuff in unnamed lacustrine forma- Deffeyes (1959b). Lander County. tion of Pliocene age.

43. Reese River, Lander County .......... do . . .

44. Jersey Valley, Pershing County*.. ...do..........

1 Zeolite identified as heulandite. 


\section{TABLE 1.-Occurrences of clinoptilolite in sedimentary rocks of the conterminous United States-Continued}

\begin{tabular}{|c|c|c|c|}
\hline & Locality & Occurrence & References \\
\hline \multicolumn{4}{|c|}{ Nevada-Continued } \\
\hline 45. & $\begin{array}{l}\text { Near Lovelock, sec. } 20, \text { T. } 28 \text { N., } \\
\text { R. } 30 \text { E., Pershing County.* }\end{array}$ & $\begin{array}{l}\text { Tuff in unnamed lacustrine forma- } \\
\text { tion of late Tertiary age. }\end{array}$ & $\begin{array}{l}\text { R. A. Sheppard (unpub. } \\
\text { data). }\end{array}$ \\
\hline 46. & $\begin{array}{l}\text { Near Eastgate, sec. } 28, \text { T. } 17 \text { N., } \\
\text { R. } 36 \text { E., Churchill County.* }\end{array}$ & , ndo & Do. \\
\hline 47. & Teels Marsh, Mineral County & $\begin{array}{l}\text { Tuff in lacustrine deposit of Qua- } \\
\text { ternary age. }\end{array}$ & $\begin{array}{l}\text { Hay }(1964,1966) ; \quad \text { Cook } \\
\text { and Hay }(1965) \text {. }\end{array}$ \\
\hline 48. & $\begin{array}{l}\text { Near Silver Peak, Esmeralda } \\
\text { County.* }\end{array}$ & $\begin{array}{l}\text { Tuff in the Esmeralda Formation of } \\
\text { Miocene and Pliocene age. }\end{array}$ & $\begin{array}{l}\text { Moiola }(1964 \mathrm{a}, 1964 \mathrm{~b}) \\
\text { Robinson }(1966) \text {. }\end{array}$ \\
\hline 49. & $\begin{array}{l}\text { Near Goldfield, Esmeralda } \\
\text { County. }\end{array}$ & $\begin{array}{l}\text { Tuffaceous sandstone in the Siebert } \\
\text { Formation of Tertiary age. }\end{array}$ & $\begin{array}{l}\text { R. J. Moiola (written com- } \\
\text { mun., 1964). }\end{array}$ \\
\hline 50. & Nevada Test Site, Nye County*-.. & Tuff and lapilli tuff of Tertiary age. & $\begin{array}{l}\text { Gibbons and others (1960); } \\
\text { Hoover (1966, 1968); } \\
\text { Hoover and Shepard } \\
(1965) \text {. }\end{array}$ \\
\hline
\end{tabular}

\section{California}

52. Death Valley, sec. 2, T. 26 N., R. Tuff in the Furnace Creek Forma- J. F. McAllister (written 2 E., Inyo County.* tion of Pliocene age.

53. Lake Tecopa, Inyo County*..... . Tuff in lacustrine deposit of Pleisto- Sheppard and Gude (1968). cene age.

54. Owens Lake, Inyo County ...... Tuff and tuffaceous sediments of Hay $(1964,1966)$. Pleistocene age.

55. Mojave Desert, eastern Kern Tuff and tuffaceous rocks in num- Kerr and Cameron (1936); County and San Bernardino erous formations of late Tertiary Ames and others (1958); $\begin{array}{lll}\text { County and San Bernardino } & \begin{array}{l}\text { erous formations of late Tertiary } \\ \text { and Quaternary age. }\end{array} & \text { Ames and others (1958) }\end{array}$ and Quaternary age. $\quad \begin{aligned} & \text { Sheppard and Gude } \\ & (1964,1965,1969 b) .\end{aligned}$

56. Near Branciforte Creek, Santa Tuffaceous sandstone in the Santa Gilbert and McAndrews Cruz County. $\quad$ Margarita Formation of Miocene (1948). age.

57. Near Nipomo, San Luis Obispo Tuff in the Obispo Formation of Bramlette and Posnjak $\begin{array}{ll}\text { County.* } & \text { (1933); Surdam and Hall }\end{array}$ (1968).

58. Near Oakview, Ventura County _. _ Bentonite in the Modelo Formation Kerr (1931). of Miocene age.'

59. Near San Pedro, Los Angeles Dolomitic sandstone in the Mon- Spotts and Silverman County.

terey Formation of Miocene age. (1966)

\section{Arizona}

60. Near Wikieup, Mohave County*.. Tuff in unnamed lacustrine forma- Sheppard (1969). tion of Pliocene age.

61. Near Dome, Yuma County*..... Bentonite and tuff in unnamed Bramlette and Posnjak lacustrine formation of late Ter- (1933). tiary age.

62. Near Horseshoe Reservoir, sec. 3, Tuff in the Verde Formation of R. A. Sheppard (unpub. T. 7 N., R. 6 E., Maricopa Pliocene(?) or Pleistocene age. data).

63. Near Nutrioso, Apache County ... Tuff and sandstone in unnamed for- Wrucke (1961). mation of Tertiary age.

64. Near Morenci, Greenlee County _.. Tuff and lapilli tuff in unnamed for- Sheppard (1969). mation of Tertiary age.

65. Along San Simon Creek, Cochise Tuft in unnamed lacustrine forma- Sand and Regis (1966); and Graham Counties.* tion of late Cenozoic age.

\section{New Mexico}

66. Near Bayard, Grant County*.... Tuff in the Sugarlump Tuff of Oligo- Jones and others (1967, p. cene age. 104).

67. Near Cuba, sec. 25, T. 20 N., R. 1 Tuff and tuffaceous sandstone in the E.S.Santos (oral commun., W., Sandoval County. Brushy Basin Member of the 1970). Morrison Formation of Jurassic age.

1 Zeolite identified as heulandite. 
TABLE 1.-Occurrences of clinoptilolite in sedimentary rocks of the conterminous United States-Continued

\begin{tabular}{ccc}
\hline Locality & Occurrence & References \\
\hline 68. Near Coy City, Karnes County _.- Tuff and tuffaceous sandstone in the Weeks and others (1958); \\
Jackson Group of Eocene age. \\
Weeks and Eargle (1963). \\
69. Near Tilden, McMullen County*-- Tuff in Jackson Group of Eocene Eargle (1968, p. D24); \\
age and the Gueydan Formation \\
of Oligocene or Miocene age. \\
(1968).
\end{tabular}

\section{Mississippi}

70. Near Meridian, Lauderdale County.
Tuffaceous sandstone in the Merid- Wermund and Moiola ian Sand of Eocene age. (1966).

\section{Alabama}

71. Near Nettleboro, Clarke County_ _ Tuffaceous sandstone in the Merid- Wermund and Moiola ian Sand of Eocene age. (1966).

72. Near McKenzie, Butler County*_. Tuff and tuffaceous claystone in the Reynolds (1966). Tallahatta Formation of Eocene age.

Kentucky

73. Near Paducah, McCracken County.
Claystone in the Clayton(?) For- Sohn and others mation of Paleocene age and clay Finch (1966).

in the Porters Creek Clay of

Paleocene age.

\section{Tennessee}

74. Near Jackson, Madison County _.. Fossiliferous rock of Paleocene age.1 Switzer and Boucot (1955).

\section{Florida}

75. Near Caryville, Washington County.
Suwanee Limestone of Oligocene Switzer and Boucot (1955). age. 1

\section{South Carolina}

76. Near Coosawhatchie, Jasper County.

77. Central South Carolina
Clay in the Hawthorn Formation Heron and Johnson (1966). of Miocene age and the Santee Limestone of Eocene age.

Mudstone in the Black Mingo For- Heron (1969). mation of Paleocene and Eocene age.

\section{North Carolina}

78. Near Eward, Beaufort County .... Phosphorite in the Pungo River Rooney and Kerr (1964); Formation of Miocene age. Cathcart (1968). 
Localities where beds are at least 1 foot thick and consist of at least 75 percent clinoptilolite (table 1) are marked by an asterisk. Some beds that have a relatively low content of clinoptilolite probably originally contained a high content of crystal and rock fragments. Other clinoptilolite-poor beds contain much relict vitric material or authigenic clay minerals and opal. Tuff beds rich in clinoptilolite are commonly white to pale gray, are very well indurated, and are low in porosity, and they generally break with a blocky to conchoidal fracture.

\section{ECONOMIC CONSIDERATIONS}

Clinoptilolite is used on a very limited scale in the United States in the extraction of radioactive cesium from atomic-energy waste effluent (Brown, 1962). The ion exchange and molecular sieve properties of clinoptilolite coupled with a seemingly low cost of mining suggest a much wider and more varied application in future years. Barrer and Makki (1964) showed that a wide range of sorbents could be produced from clinoptilolite by acid treatment. Thus, the potential uses of clinoptilolite are considerably increased by chemical and structural modifications of the natural material.

Clinoptilolite is currently mined and used for a variety of industrial and agricultural processes in Japan. Minato and Utada (1969) described the following uses: desiccant for gases, separator of oxygen from air, adsorbent for obnoxious odors in farm yards, filler and whitening agent for paper, and a soil conditioner to increase the effectiveness of chemical fertilizers. More clinoptilolite is mined in Japan for the last use than for any of the other uses listed.

Laboratory and pilot-plant studies by Pacific Northwest Laboratory, Battelle Memorial Institute, Richland, Wash. (Mercer, 1969; Mercer and others, 1970), indicate that clinoptilolite is effective in the removal of ammonia from wastewater. Clinoptilolite used in these studies was obtained from Hector, Calif. (Ames and others, 1958). Recent legislation in some States and cities has made the removal of ammonia a necessary step in the treatment of wastewater in many parts of the United States. Although more research is needed on the durability, reliability of different sources, and methods of regeneration (Holcomb, 1970), large quantities of this zeolite would be required for wastewater treatment. Mercer $(1969$, p. 210) estimated on the basis of a pilot-plant study that 480,000 cubic feet of clinoptilolite would be required to treat the wastewater presently discharged from Detroit, Mich. 


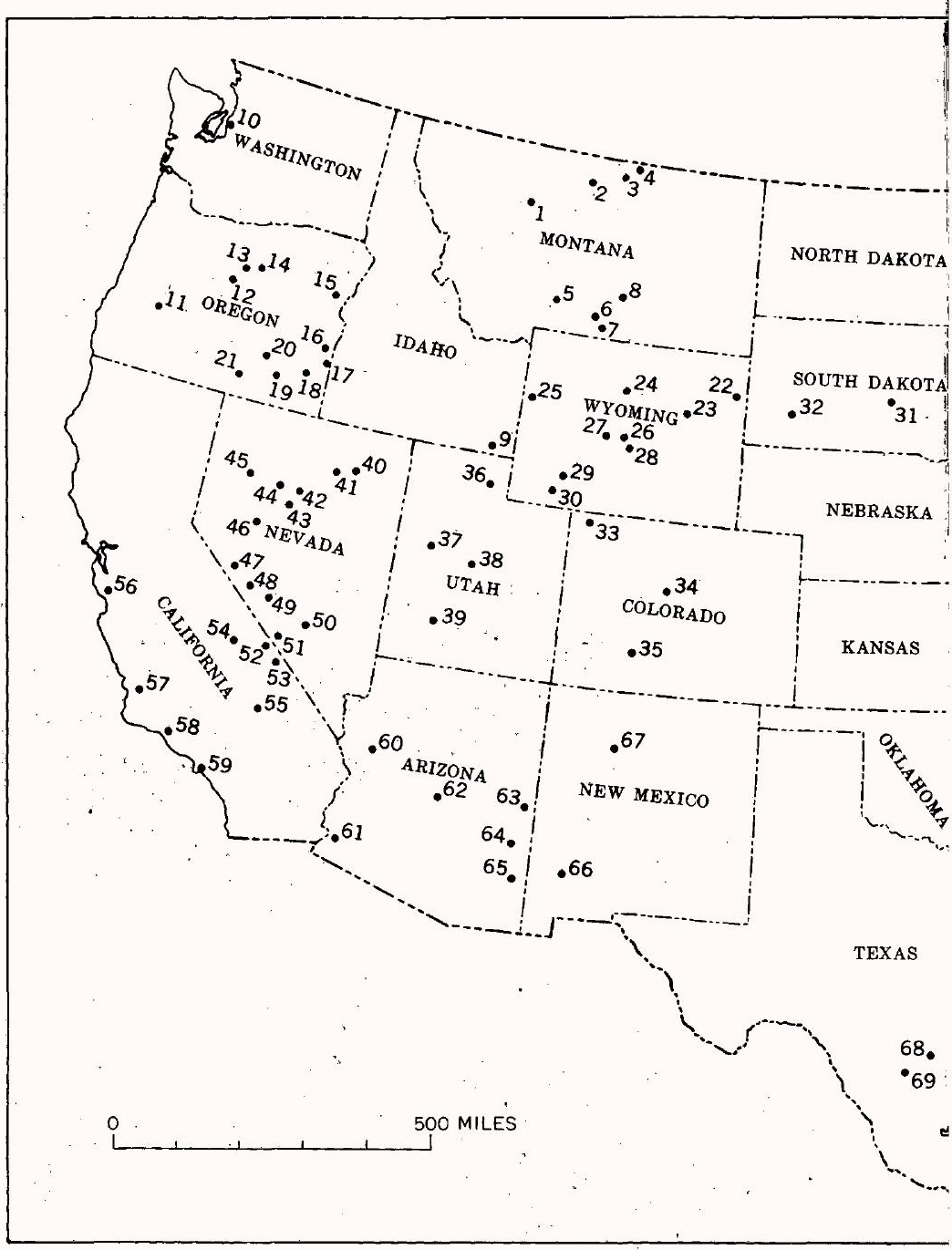

FIGURE 3.-Map showing occurrences of clinoptilolite in sedimentary rocks of the

\section{REFERENCES CITED}

Alietti, Andrea, 1968, Heulanditi e clinoptiloliti: Mineralog. et Petrog. Acta, v. 13, p. 119-137 (includes English summ.).

Ames, L. L., Jr., Sand, L. B., and Goldich, S. S., 1958, A contribution on the Hector, California, bentonite deposit: Econ. Geology, v. 53, no. 1, p. 22-37.

Anderson, J. J., 1969, Oligocene and Miocene(?) volcanic arenite sedimentation, southern High Plateaus, Utah, in Abstracts for 1968: Geol. Soc. America Spec. Paper 121, p. 586.

Barrer, R. M., and Makki, M. B., 1964, Molecular sieve sorbents from clinoptilolite: Canadian Jour. Chemistry, v. 42, no. 6, p. 1481-1487.

Berg, R. B., 1969, Bentonite in Montana: Montana Bur. Mines and Geology Bull. $74,34 \mathrm{p}$. 


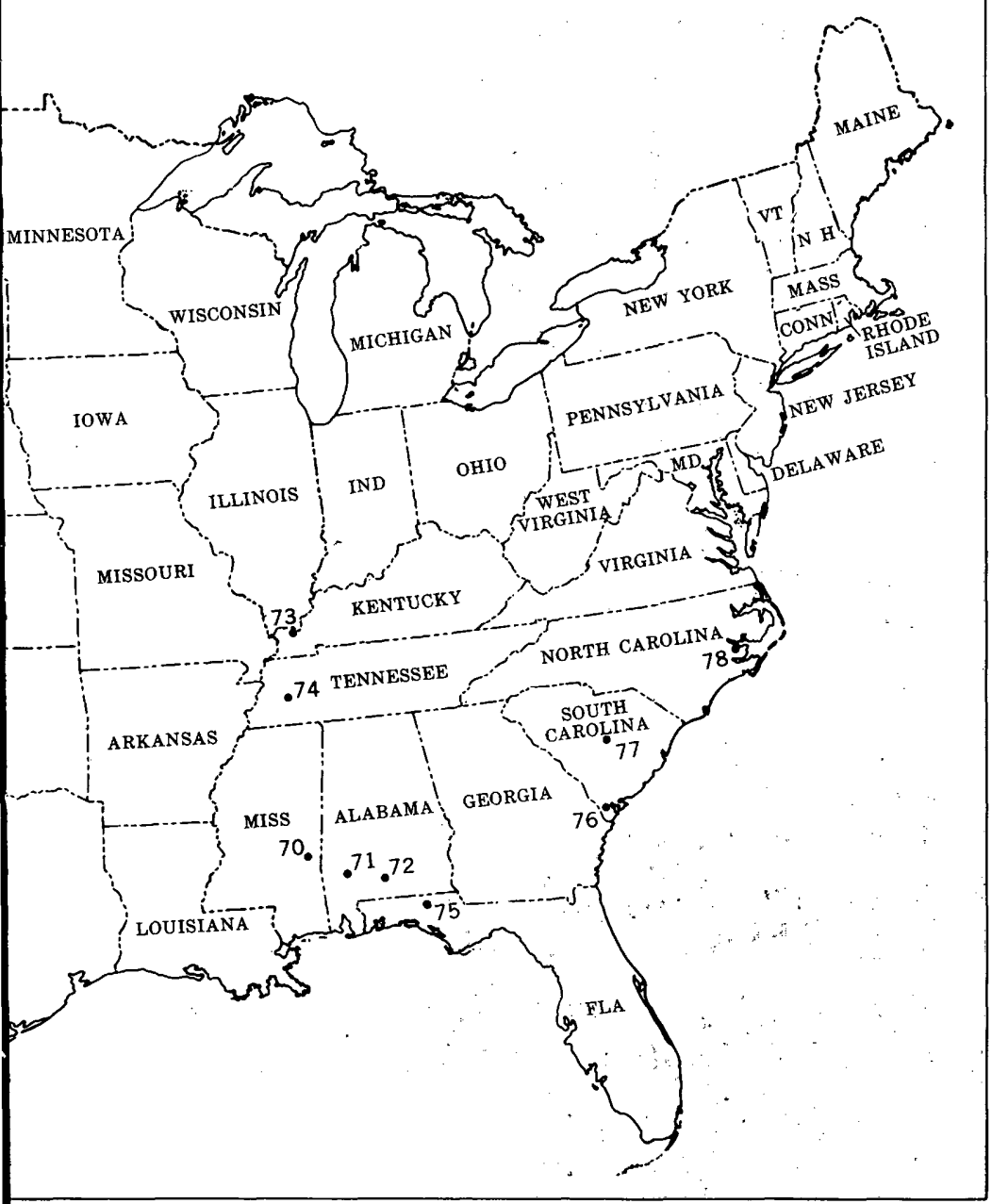

conterminous United States. Data for numbered localities are given in table 1.

Boles, J. R., 1968, Zeolites and authigenic feldspar along a part of the Beaver Rim, Fremont County, Wyoming: Laramie, Wyoming Univ. M.S. thesis, 64 p.

Bramlette, M. N., and Posnjak, Eugen, 1933, Zeolitic alteration of pyroclastics: Am. Mineralogist, v. 18, no. 4, p. 167-171.

Brown, R. E., 1962, The use of clinoptilolite: Ore Bin, v. 24, no. 12, p. 193-197.

Cathcart, J. B., 1968, Phosphate in the Atlantic and Gulf Coastal Plains, in Brown, L. F., Jr., ed., Fourth forum on geology of industrial minerals, Austin, Texas, 1968, Proceedings: Texas Univ. Bur. Econ. Geology, p. 23-34.

Cobban, W. A., 1955, Cretaceous rocks of northwestern Montana, in Billings Geological Society Guidebook 6th Annual Field Conference, September 1955: p. 107-119.

Cook, H. E., and Hay, R.L., 1965, Salinity control of zeolite reaction rates in Teels 
Marsh, Nevada, in Abstracts for 1964: Geol. Soc. America Spec. Paper 82, p. 31-32.

Cornwall, H. R., 1962, Calderas and associated volcanic rocks near Beatty, Nye County, Nevada, in Engel, A. E. J., James, H. L., and Leonard, B. F., eds., Petrologic studies (Buddington volume): New York, Geol. Soc. America, p. 357-371.

Deffeyes, K. S., 1959a, Zeolites in sedimentary rocks: Jour. Sed. Petrology, v. 29, no. 4 , p. $602-609$.

- 1959b, Erionite from Cenozoic tuffaceous sediments, central Nevada: Am. Mineralogist, v. 44, nos. 5-6, p. 501-509.

Eargle, D. H., 1968, Nomenclature of formations of Claiborne Group, middle Eocene, Coastal Plain of Texas: U.S. Geol. Survey Bull. 1251-D, 25 p.

Finch, W. I., 1966, Geologic map of the Paducah West and part of the Metropolis quadrangles, Kentucky-Illinois: U.S. Geol. Survey Geol. Quad. Map GQ-557.

Fisher, R. V., 1962, Clinoptilolite tuff from the John Day Formation, eastern Oregon: Ore Bin, v. 24, no. 12, p. 197-203.

1963, Zeolite-rich beds of the John Day Formation, Grant and Wheeler Counties, Oregon: Ore Bin, v. 25, no. 11, p. 185-197.

Fox, R. D., 1966, Geology and ground-water resources of the Cascade-Ulm area, Montana: Montana Bur. Mines and Geology Bull. 52, 64 p.

Gibbons, A. B., Hinrichs, E. N., and Botinelly, Theodore, 1960, The role of impermeable rocks in controlling zeolitic alteration of tuff, in Short papers in the geological sciences: U.S. Geol. Survey Prof. Paper 400-B, p. B473-B475.

Gilbert, C. M., and McAndrews, M. G., 1948, Authigenic heulandite in sandstone, Santa Cruz County, California: Jour. Sed. Petrology, v. 18, no. 3, p. 91-99.

Goodwin, J. H., and Surdam, R. C., 1967, Zeolitization of tuffaceous rocks of the Green River Formation, Wyoming: Sci., v. 157, no. 3786, p. 307-308.

Hay, R. L., 1962, Origin and diagenetic alteration of the lower part of the John Day Formation near Mitchell, Oregon, in Engel, A. E. J., James, H. L., and Leonard, B. F., eds., Petrologic studies (Buddington volume): New York, Geol. Soc. America, p. 191-216.

- 1963, Stratigraphy and zeolitic diagenesis of the John Day Formation of Oregon: California Univ. Pubs. Geol. Sci., v. 42, no. 5, p. 199-262.

— 1964, Phillipsite of saline lakes and soils: Am. Mineralogist, v. 49, nos. 9-10, p. 1366-1387.

1966, Zeolites and zeolitic reactions in sedimentary rocks: Geol. Soc. America Spec. Paper 85, $130 \mathrm{p}$.

Heinrich, E. W., 1963, Notes on western mineral occurrences: Am. Mineralogist, v. 48 , nos. $9-10$, p. $1172-1174$.

Heron, S. D., Jr., 1969, Mineralogy of the Black Mingo mudrocks: South Carolina Div. Geology Geol. Notes, v. 13, no. 1, p. 27-41.

Heron, S. D., Jr., and Johnson, H. S., Jr., 1966, Clay mineralogy, stratigraphy, and structural setting of the Hawthorn Formation, Coosawhatchie district, South Carolina: Southeastern Geology, v. 7, no. 2, p. 51-63.

Hey, M. H., and Bannister, F. A., 1934, "Clinoptilolite," a silica-rich variety of heulandite, Part 7 of Studies on the zeolites: Mineralog. Mag., v. 23, no. 145, p. $556-559$.

Holcomb, R. W., 1970, Waste-water treatment-The tide is turning: Sci., v. 169, no. 3944 , p. $457-459$.

Hoover, D. L., 1966, Physical and chemical changes during zeolitization of vitric tuffs and lava flows, Nevada Test Site, in Abstracts for 1965: Geol. Soc. America Spec. Paper 87, p. 286-287.

- 1968, Genesis of zeolites, Nevada Test Site, in Eckel, E. B., ed., Nevada Test Site: Geol. Soc. America Mem. 110, p. 275-284. 
Hoover, D. L., and Shepard, A. O., 1965, Zeolite zoning in volcanic rocks at the Nevada Test Site, Nye County, Nevada [abs.]: Am. Mineralogist, v. 50, nos. $1-2$, p. 287.

Jones, W. R., Hernon, R. M., and Moore, S. L., 1967, General geology of Santa Rita quadrangle, Grant County, New Mexico: U.S. Geol. Survey Prof. Paper 555, $144 \mathrm{p}$.

Kerr, P. F., 1931, Bentonite from Ventura, California: Econ. Geology, v. 26, no. 2, p. 153-168.

Kerr, P. F., and Cameron, E. N., 1936, Fuller's earth of bentonitic origin from Tehachapi, California: Am. Mineralogist, v. 21, no. 4, p. 230-237.

Kirov, G. N., 1965, Calcium-rich clinoptilolite from the eastern Rhodopes: Sofia Univ. Annuaire, Fac. Geologie et Geographie, v. 60, p. 193-200.

Kittleman, L. R., Green, A. R., Hagood, A. R., Johnson, A. M., McMurray, J. M., Russell, R. G., and Weeden, D. A., 1965, Cenozoic stratigraphy of the Owyhee region, southeastern Oregon: Oregon Univ. Mus. Nat. History Bull. 1, 45 p.

Love, J. D., 1970, Cenozoic geology of the Granite Mountains area, central Wyoming: U.S. Geol. Survey Prof. Paper 495-C, 154 p.

McBride, E. F., Lindemann, W. L., and Freeman, P. S., 1968, Lithology and petrology of the Gueydan (Catahoula) Formation in south Texas: Texas Univ. Bur. Econ. Geology Rept. Inv. 63, 122 p.

Mason, B. H., and Sand, L. B., 1960, Clinoptilolite from Patagonia-The relationship between clinoptilolite and heulandite: Am. Mineralogist, v. 45, nos. 3-4, p. 341-350.

Mercer, B. W., 1969, Clinoptilolite in water-pollution control: Ore Bin, v. 31, no. 11, p. 209-213.

Mercer, B. W., Ames, L. L., Touhill, C. J., Van Slyke, W. J., and Dean, R. B., 1970, Ammonia removal from secondary effluents by selective ion exchange: Water Pollution Control Federation Jour., v. 42, no. 2, pt. 2, p. R95-R107.

Minato, Hideo, and Takano, Yukio, 1964, An occurrence of potassium-clinoptilolite from Itaya, Yamogata Prefecture, Japan: Nendo Kagaku, v. 4, p. 12-22.

Minato, Hideo, and Utada, Minoru, 1969, Zeolite, in The clays of Japan-International Clay Conference, Tokyo, 1969: Japan Geol. Survey, p. 121-134.

Moiola, R. J., 1964a, Origin of authigenic silicate minerals in the Esmeralda "Formation" of western Nevada, in Abstracts for 1963: Geol. Soc. America Spec. Paper 76 , p. 116-117.

1964b, Authigenic mordenite in the Esmeralda "formation," Nevada: Am. Mineralogist, v. 49 , nos. 9-10, p. 1472-1474.

Moore, J. G., and Peck, D. L., 1962, Accretionary lapilli in volcanic rocks of the western continental United States: Jour. Geology, v. 70, no. 2, p. 182-193.

Mumpton, F. A., 1960, Clinoptilolite redefined: Am. Mineralogist, v. 45, nos. 3-4, p. 351-369.

Peck, D. L., Griggs, A. B., Schlicker, H. G., Wells, F. G., and Dole, H. M., 1964, Geology of the central and northern parts of the Western Cascade Range in Oregon: U.S. Geol. Survey Prof. Paper 449, 56 p.

Pirsson, L. V., 1890, On mordenite: Am. Jour. Sci., 3d ser., v. 40, p. 232-237; Yale Bicentennial Pub. Contr. Mineralogy, 1901, p. 178-182.

Ratté, J. C., and Steven, T. A., 1967, Ash flows and related volcanic rocks associated with the Creede caldera, San Juan Mountains, Colorado: U.S. Geol. Survey Prof. Paper 524-H, $58 \mathrm{p}$.

Regis, A. J., and Sand, L. B., 1966, K-Na phillipsite, Crooked Creek, Oregon [abs.]: Am. Mineralogist, v. 51, nos. 1-2, p. 270.

1967, Lateral gradation of chabazite to herschelite in the San Simon basin [abs.], in Bailey, S. W., ed., Clays and clay minerals-Clay Minerals Conference, 15th, Pittsburgh, Pa., 1966, Proceedings: New York, Pergamon Press (Internat. Ser. Mons. Earth Sci., v. 27), p. 193. 
Regnier, J. P. M., 1960, Cenozoic geology in the vicinity of Carlin, Nevada: Geol. Soc. America Bull., v. 71, no. 8, p. 1189-1210.

Reynolds, W. R., 1966, Stratigraphy and genesis of clay mineral and zeolite strata in the lower Tertiary of Alabama, in Copeland, C. W., ed., Facies changes in the Alabama Tertiary-Alabama Geological Society Guidebook 4th Annual Field Trip, December 1966: Alabama Geol. Soc., p. 26-37.

Roberts, A. E., 1963, The Livingston Group of south-central Montana, in Short papers in geology and hydrology: U.S. Geol. Survey Prof. Paper 475-B, p. B86-B92.

Robinson, P. T., 1966, Zeolitic diagenesis of Mio-Pliocene rocks of the Silver Peak Range, Esmeralda County, Nevada: Jour. Sed. Petrology, v. 36, no. 4, p. $1007-$ 1015.

Rooney, T. P., and Kerr, P. F., 1964, Clinoptilolite-A new occurrence in North Carolina phosphorite: Sci., v. 144, no. 3625 , p. 1453.

Sand, L. B., and Regis, A. J., 1966, An unusual zeolite assemblage, Bowie, Arizona, in Abstracts for 1965: Geol. Soc. America Spec. Paper 87, p. 145-146.

Schaller, W. T., 1932, The mordenite-ptilolite group, clinoptilolite, a new species: Am. Mineralogist, v. 17 , no. 4, p. 128-134.

Schultz, L. G., 1961, Preliminary report on the geology and mineralogy of clays on the Pine Ridge Indian Reservation, South Dakota, with a chapter on Usability tests, by H. P. Hamlin: U.S. Geol. Survey open-file rept., 60 p.

1963, Nonmontmorillonitic composition of some bentonite beds, in Bradley, W. F., ed., Clays and clay minerals [v. 11]-National Conference on Clays and Clay Minerals, 11th, Ottawa, 1962, Proceedings: New York, Macmillan Co. (Internat. Ser. Mons. Earth Sci., v. 13), p. 169-177.

Shepard, A. O., 1961, A heulandite-like mineral associated with clinoptilolite in tuffs of Oak Spring formation, Nevada Test Site, Nye County, Nevada, in Short papers in the geologic and hydrologic sciences: U.S. Geol. Survey Prof. Paper 424-C, p. C320-C323.

Shepard, A. O., and Starkey, H. C., 1964, Effect of cation exchange on the thermal behavior of heulandite and clinoptilolite, in Short papers in geology and hydrology: U.S. Geol. Survey Prof. Paper 475-D, p. D89-D92.

Sheppard, R. A., 1969, Zeolites, in Mineral and water resources of Arizona: U.S. 90th Cong., 2d sess., Senate Comm. Interior and Insular Affairs, Comm. Print, p. 464-467.

Sheppard, R. A., and Gude, A. J., 3d, 1964, Reconnaissance of zeolite deposits in tuffaceous rocks of the western Mojave Desert and vicinity, California, in Geological Survey research 1964: U.S. Geol. Survey Prof. Paper 501-C, p. C114-C116.

1965, Zeolitic authigenesis of tuffs in the Ricardo Formation, Kern County, southern California, in Geological Survey research 1965: U.S. Geol. Survey Prof. Paper 525-D, p. D44-D47.

1968, Distribution and genesis of authigenic silicate minerals in tuffs of Pleistocene Lake Tecopa, Inyo County, California: U.S. Geol. Survey Prof. Paper 597, $38 \mathrm{p}$.

-_ 1969a, Authigenic fluorite in Pliocene lacustrine rocks near Rome, Malheur County, Oregon, in Geological Survey research 1969: U.S. Geol. Survey Prof. Paper 650-D, p. D69-D74 [1970].

$1969 \mathrm{~b}$, Diagenesis of tuffs in the Barstow Formation, Mud Hills, San Bernardino County, California: U.S. Geol. Survey Prof. Paper 634, 35 p.

Sheppard, R. A., Gude, A. J., 3d, and Munson, E. L., 1965, Chemical composition of diagenetic zeolites from tuffaceous rocks of the Mojave Desert and vicinity, California: Am. Mineralogist, v. 50, nos. 1-2, p. 244-249. 
Sheppard, R. A., and Walker, G. W., 1969, Zeolites, in Mineral and water resources of Oregon: U.S. 90th Cong., 2d sess., Senate Comm. Interior and Insular Affairs, Comm. Print, p. 268-272.

Sims, J. D., 1969, Thermodynamic model for zeolitic diagenesis in the Livingston Group, northern Crazy Mountains, Montana, in Abstracts for 1968: Geol. Soc. America Spec. Paper 121, p. 636-637.

Sohn, I. G., Herrick, S. M., and Lambert, T. W., 1961, Replaced Paleocene Foraminifera in the Jackson Purchase area, Kentucky, in Short papers in the geologic and hydrologic sciences: U.S. Geol. Survey Prof. Paper 424-B, p. B227-B228.

Spotts, J. H., and Silverman, S. R., 1966, Organic dolomite from Point Fermin, California: Am. Mineralogist, v. 51, no. 7, p. 1144-1155.

Studer, H. P., 1967, Mineral analysis of natural zeolite deposits [abs.], in Bailey, S. W., ed., Clays and clay minerals-Clay Minerals Conference, 15th, Pittsburgh, Pa., 1966, Proceedings: London and New York, Pergamon Press (Internat. Ser. Mons. Earth Sci., v. 27), p. 187.

Surdam, R. C., and Hall, C. A., 1968, Zeolitization of the Obispo Formation, Coast Ranges of California, in Abstracts for 1966: Geol. Soc. America Spec. Paper 101, p. 338 .

Switzer, G. S., and Boucot, A. J., 1955, The mineral composition of some microfossils: Jour. Paleontology, v. 29, no. 3, p. 525-533.

Van Houten, F. B., 1964, Tertiary geology of the Beaver Rim area, Fremont and Natrona Counties, Wyoming: U.S. Geol. Survey Bull. 1164, 99 p.

Walker, G. W., and Repenning, C. A., 1965, Reconnaissance geologic map of the Adel quadrangle, Lake, Harney, and Malheur Counties, Oregon: U.S. Geol. Survey Misc. Geol. Inv. Map I-446.

Walker, G. W., and Swanson, D. A., 1968a, Summary report on the geology and mineral resources of the Harney Lake and Malheur Lake areas of the Malheur National Wildlife Refuge, north-central Harney County, Oregon: U.S. Geol. Survey Bull. 1260-L, 17 p.

$1968 \mathrm{~b}$, Summary report on the geology and mineral resources of the Poker Jim Ridge and Fort Warner areas of the Hart Mountain National Antelope Refuge, Lake County, Oregon: U.S. Geol. Survey Bull. 1260-M, 16 p.

Waters, A. C., 1966, Stein's Pillar area, central Oregon: Ore Bin, v. 28, no. 8, p. 137144.

Weeks, A. D., and Eargle, D. H., 1963, Relation of diagenetic alteration and soilforming processes to the uranium deposits of the southeast Texas Coastal Plain, in Swineford, Ada, ed., Clays and clay minerals, volume 10-National Conference on Clays and Clay Minerals, 10th, 1961, Proceedings: New York, Macmillan Co. (Internat. Ser. Mons. Earth Sci., v. 12), p. 23-41.

Weeks, A. D., Levin, Betsy, and Bowen, R. J., 1958, Zeolitic alteration of tuffaceous sediments and its relation to uranium deposits in the Karnes County area, Texas [abs.]: Geol. Soc. America Bull., v. 69, no. 12, pt. 2, p. 1659; Econ. Geology, v. 53, no. 7, p. 928-929.

Wermund, E. G., and Moiola, R. J., 1966, Opal, zeolites, and clays in an Eocene neritic bar sand: Jour. Sed. Petrology, v. 36, no. 1, p. 248-253.

Wilcox, R. E., and Fisher, R. V., 1966, Geologic map of the Monument quadrangle, Grant County, Oregon: U.S. Geol. Survey Geol. Quad. Map GQ-541.

Wrucke, C. T., 1961, Paleozoic and Cenozoic rocks in the Alpine-Nutrioso area, Apache County, Arizona: U.S. Geol. Survey Bull. 1121-H, 26 p. 


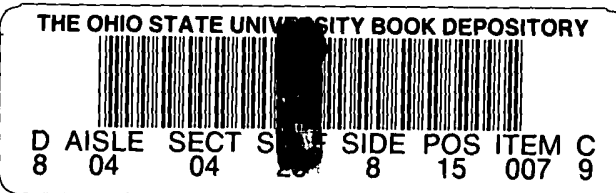

